\title{
INCREASING TEACHER PERFORMANCE FOR SCHOOL QUALITY IMPROVEMENT
}

\author{
Nurhizrah Gistituatia

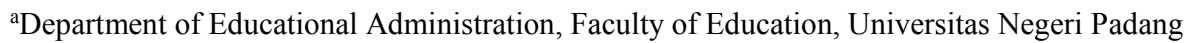 \\ Padang, Indonesia
}

Corresponding e-mail: ng@fip.unp.ac.id

\begin{abstract}
From the studies that have been conducted concerning teacher performance at several schools and also from the interviews with several principals in West Sumatera shown that teacher performance has not yet as it is expected. It cannot be denied that teacher performance is the heart of the school in carrying out its function. Without good performance of the teacher, it will be impossible for the school to produce students with high quality achievement. In other words, the quality of education at school cannot be achieved without good performance of the teacher. This article aims to propose several ways that can be done by school principals in order to increase teacher performance for school quality improvement. More specific, this article firstly discusses the meaning of teacher performance; then follow by discussing the factors that influence teacher performance; and finally proposes the ways to increase teacher performance.
\end{abstract}

Keywords: teacher performance, school principal, school quality, school improvement

\section{INTRODUCTION}

School is the most important education organization created for the development of quality students. However, the students with high quality can only be produced by the school with high quality too. Therefore, it is very important for the school principals and/or the school supervisors to always put their efforts in improving the quality of their schools. Having schools with high quality standard is the most important mission of the Ministry of Education in Indonesia; however, up to now the Indonesian Government, including schools still struggling to accomplish that mission.

There are many factors influence the quality of schools. One of the important factors is teacher performance. Most of the studies related to school quality or school effectiveness clearly depended upon effective classroom. See for example [1], [2], [3], [4], [5] and [6]. It is almost true to say that an effective classroom depends on the performance of the teachers. As it is known that teacher is a leader in the classroom activities. How "good" the classroom will be, it depends on how "good" the teachers perform his/her task and responsibility. The prior task and responsibility of the teacher is to conduct teaching and learning, and to help students in achieving their intended goals. If a teacher success in conducting his/her task and responsibility, it can be said that he/she has good performance. Thus, it can be said that quality of school will be determined by teacher performance, by mean how good the teacher performing his/her task and responsibility.

However, from the studies that have been conducted at different levels of education in West Sumatera found that teacher performance were still not as good as it is expected. See for example [7], [8], [9], [10], and [11]. From the interview with several school principals in the city of Padang and Solok in 2016 (during the community services activities) indicated that there were still a number of teachers who did not prepare their teaching plan properly. From that interview also found that several teachers were still lack of ability to use new methods, approaches, or models in their teaching and learning process; they were reluctant to do the teaching innovation; having low commitment, discipline, and motivation in doing their works. These phenomenon were indicated that teacher performance still unsatisfied. Since teacher performance is one of the important factors in determining a quality of school; therefore, in order to improve the quality of school; increasing teacher performance need to be given attention more curiously by the government, especially by the school principals and school supervisors. 
Base on the above argument, this article will proposes several ways that can be used by school principals and/or school supervisors in increasing teacher performance in order to improve the quality of school. More specific, this article firstly discusses the meaning of teacher performance; then discusses the factors that influence teacher performance; and finally proposes the ways to increase teacher performance.

\section{MATERIAL AND METHOD}

The purposes of this paper is to propose ways to increase teacher performance for school quality improvement. This article is written base on the literature review concerning job performance in general, and teacher performance in particular, and also base on the reseacrh findings that have been conducted recently. Some materials have been used, such as text books, research findings, publication, internet, and online databases. The article consists of introduction, material and methods, and discussion. Three topics were discuced, namely: (1) definition of teacher performance; (2) factors influencing teacher performance; and (3) the ways to improve teacher performance.

\section{RESULT AND DISCUSSION}

As it has been mentioned previously that the aim of this paper is to propose ways in increasing teacher's performance for school quality improvement. In achieving the purpose of this paper, three related topics were discussed in this paper, namely, (1) definition of teacher perfomance; (2) factors influencing teacher perfomance; and (3) how to improve teacher perfomance. Each of these topics will be elaborated as follows.

\subsection{Definition of Teacher Performance}

Many experts have proposed their views on the definition of teacher performance. In Kamus Umum Bahasa Indonesia (2003), performance (kinerja) is defined as achievable things, visible achievement, and working ability. According to Gibson et.al. Performance is similar to working achievement i.e. the result achieved from a certain work [12]. Mangkunegara also proposes that performance is the result of work in quality and quantity achieved by employees in performing his/her tasks in accordance with the responsibilities given to them [13]. On the other hand, Fatah defines performance as the way of producing something in achieving the desired results and goals [14]. Similar to this, Lako asserts that performance is any movement, action, implemented or conscious actions directed to achieve a particular goal or target [15]. Meanwhile, according to Reksohadiwiryo, performance means willingness and ability to do work [16].

From the various definitions above, it can be concluded that perfomance entails two meanings, namely (1) as a procees of work; and (2) as a result of work. As it was mention by Sonnentag, Volmer, and Spychala that performance has multi-demention concept. Performance can be conceptualized as a process or behavioral and as an outcome [17]. These two demension concept of performance can be distinguished from each other. As a process, performance refers to individuals behavior at work or in doing their works. It can be seen, ie. through their ability and willingness to do their work. On the other hand, performance as an outcome refers to the result of the individuals' behavior or the result of work achieved by individuals, both in quantity and quality. Although performance as a process or behavior and as an outcome can be distinguished; but empirically, the process and outcome are related. It is inevitable that the performance as an outcome, both quality and quantity will be determined by individuals' behaviour at work. As Johnson said that behavioural variable of performance are very important for outcomes variable of performance [18].

Related to teachers' tasks and responsibilities, the performance of teachers can be defined as a result of teachers' work, both in quality and quantity, in teaching and mentoring the students; and it is also can be defined as teachers' behavior, include ability and willingness to carry out their tasks and responsibilities. Thus, teachers' performance can be measured through the result of their teaching and learning process, both in quantity and quality; and it also can be seen from their ability and willingness to carry out their tasks and responsibilities in teaching and learning process, and in mentoring the students.

\subsection{Factor Influencing Teacher Performance}

Teachers performance not only ditermined by teachers' ability and willingness to do the tasks or teachers' behavior in doing their task, but it can be influenced by many factors. Steers mentioned several factors that affect teacher's performance, namely intelligence, attitude, and interest in their job [19]. Furthermore, Timpe adds that incentives, discipline, and work environment can also affect performance [20]. Meanwhile Fatah mentions the 
factors that can affect the performance are motivation, facilities and infrastructure, incentives, working atmosphere, leadership, security, discipline, and work environment [14]. More specific Hersey, Blanchard, and Johnson said that the low performance of the employees can be caused of the personal problems that they faced, such as conflict with other employee, feel bored with the routinity of the tasks, and lack of attention and appreciation from the superior for their achievement in doing their duties [21].

Based on some views above, it can be concluded that there are three factors that can influence the performance of teachers. These three factors are also proposed by Simanjuntak namely, (1) internal factors, such as intelligence and working ability, discipline, motivation, and commitment; (2) organizational support, such as working environment or atmosphere, facilities and infrastructure, and job safety; and (3) managerial support, such as leadership, incentives, controlling, and supervision [22].

Given the importance of teachers' perfomance, that is as determinant factor for the school success in achieving its goals, it is necessary for the principal or supervisor to give more attention to this. If the school wish to improve teachers' performance in order to improve the quality of school, then the principals have to pay attention to the factors influencing that performance.

\subsection{Increasing Teachers Performance}

As it has been discussed above that the quality of school depends on the teachers perpormance. It is therfore essential for for the principals to always pay serious attention to teachers performance. There are various way that principals can do to increase teachers performance. Some of which are discussed below.

\subsubsection{Make School as a "Healthy" Institution}

Individuals will never be detached from their environmental influences. The way a person behaves within an organization, including an educational organization, is determined both by the person him/herself and by the organizational 'setting [23]'. The meaning of 'setting' here is the environment, culture, atmosphere, circumstances or known as' climate'-that is, everything that concerns the internal quality of the organization as it is experienced or perceived by its members. This means that the individual personality is formed from the interaction with the environment through the learning process.
The statement indicates that a person's attitude may change because of his/her interaction with the environment. As Hoy \& Miskel said that the environment will have a powerful and decisive influence on one's attitude [23]. In organizations, including schools, it is often found someone who was originally diligent became lazy or vice versa. Given the enormous influence of the environment on the change of attitudes and personality of the teachers, it is necessary for the principal to create a 'healthy' or conducive environment, which is a good and pleasant for teachers to work. There are several efforts the principal can do to make a healthy sechool or institution:

a) Formulate clear school's vision, mission, and goals which are understood and shared by all teachers. With clear vision, mission, and goals which are understood by teachers, it will make teachers know what are expected from them, and they will know exactly what to be achieved and what to do; and then they will do their best to achieve that goals. However, it is very important to keep in mind that in formulating vision has to have a time period, can be operationalized, and can be measured. Otherwise, the vision of a school organization can only remain as unachievable dreams.

b) Have a mutually agreed strategy to achieve the goal. One strategy that can be taken is strategy in making decisions. In this case, it is important for the principal to involve teachers in decision-making on matters concerning the interests of teachers and schools, including in formulating vision, mission, and goals. By involving teachers in decision-making or policy-making, they will take responsibility for implementing all that has been decided together.

c) Have and develop the necessary resources. To be able to carry out the task well, teachers need adequate resources or facilities and infrastructure. Without facilities and infrastructure, including adequate funds, it will be very difficult for teachers to carry out their tasks properly. Therefore, it is essential for the principal to constantly strive and develop resources so that teachers can work well.

d) Have a reliable and adequate administration. The successful work of teachers will be largely determined by the level of services provided by schools to teachers, such as correspondence services, promotion, and the provision of media or learning materials. It is therefore important for the principal to provide good services regarding administrative issues to teachers.

e) Have a good academic program. The success of a school depends largely on how the academic program is offered to the learners. To have a good academic program with good quality; a 
comprehenship, good, and quality planning is required; and it needs to involve the teachers in making the planning.

f) Assign human resources according to their expertise. One of the most important things in organizing is the placement of staff according to their expertise, otherwise known as 'the right man in the right place'. By placing people or teachers according to their respective fields of expertise, the teachers will be able to work well and deliver good results. Since a teacher at primary school is a classroom teacher; thus, it is suggested to the principal not to give an assignment to a teacher who mastering in teaching at the lower grade to teah at the high grade; or vice versa.

g) Develop an intimate sense of fellowship, free communication, and information sharing. Such work atmosphere will create good cooperation among individual at school; make teachers feel free to try or to make an innovation because they are not affraid to make a mistake; and which in the end can give good results. Develop such good atmosphare can be done through various activities, such as outbound, in-bound, recreation, and visiting each other.

h) Have a set of cultural and school values that are both upheld and maintained by the school community. School culture is a system of shared orientations such as norm, values, perspective, beliefs, and expectations that hold the unit together and give it a distinctive identity ${ }^{[23]}$. The existence of good organizational culture and values, such as the culture of working hard, willing to give good service, and want to succeed; which is perceived and respected by each person in the organization, especially by the teachers, is very important. Such organizational culture will make the organization run well, strong, and successful in achieving the desired goals.

\subsubsection{Develop Teachers' Professional Competence}

The performance of teachers is largely determined by their professional competence. It is therefore imperative for teachers, both individually and in groups, to constantly seek to improve it. The development of teachers' professional competence will be accomplished better if there is continuous support from the principal. There are several things that the principal can do in order to improve the professional skills of teachers include: (1) encourage teachers to take professional actions, such as performing work in accordance with the teacher's ethical code; (2) encourage teachers to participate in professional meetings locally, nationally, and internationally. In this case it is very important to seek the necessary funds by the school leaders; (3) encourage teachers to be active in profesional development through a peer group activity. In this case school principal has to give permission or support to teachers if they have to leave their class activities; and (4) make schedule time for professional discussions at school.

\subsubsection{Increase Teamwork}

One of the most consistently successful strategies to improve performance has been the use of teams and teamwork[21]. As an organization, school achievement is not a result of individual, but the work of many people. Therefore, in order to improve teachers' performance, it is necessary for the principal to improve the cooperative culture among the teachers. Many organization have found that teamwork has increased productivity, increase revenues, decreased absenteesm, and decreased turnover. But it should be keep in mind that cooperation at school should be done by teachers especially is in forming strategies to make the learners learn effectively and efficiently.

The good cooperation is based on awareness of interdependence, mutual respect, mutual understanding, mutual trust, and mutual need for each other. In this case, the teacher will carry out all the policies of the principal when the principals support the efforts of teachers to achieve their goals.

There are several things the principal can do to improve cooperation between teachers and teachers as well as between teacher and principal are: (1) create a conducive organizational climate, the atmosphere in which each individual has a sense of mutual respect, mutual trust, mutual care, and mutual openness in communication. Such good climate can only be created if the principal respect, care, appreciate, trust, understanding every teacher at school, and develops open and honest communication to every teacher; (2) develop an intimate sense of fellowship, and conduct joint activities such as out-bound and in-bound; and (3) resolve conflicts of interest and other forms of tension professionally.

\subsubsection{Have Determination to be School with Good Quality}

Work success will be largely determined by the working culture or working philosophy. The philosophy of work here means a determination that is ingrained within the principal and teacher to do their best. It is therefore essential for the principal to develop a working philosophy. The working 
philosophy that needs to be grown by the principal is a quality philosophy, which is a determination to become a school with good quality. It is the school that can meet the needs and expectations of its customers, or in other words it can satisfy customers. This quality culture must grow and develop within each teacher.

Quality begins with oneself. To have good quality, one should have intention and then proceed with making a real effort toward the achievement. Some real efforts that can be done by principal are:

a) Focus attention to the customers. This means that the attention of principal and teachers should always focus on the needs and expectations of customers and always try to meet and satisfy the needs and expectations of these customers.

b) Create a quality performance improvement team. It is important for schools to set up work teams, such as the team work of curriculum development; the team work of cooperation and school development; and the team work of learning monitoring and evaluation.

\subsubsection{Increase Commitment}

All well-designed plans will be no meaning if they are not properly implemented. To get good results, it is required high commitment from the teachers on the assigned tasks. Commitment is a promise or a person's attachment to doing things as good as possible. Highly committed people are characterized by the desire to do more than they should in carrying out the task. Therefore, the principal and teachers should have high commitment to the tasks. By having this high commitment they can show others, especially customers, that they have confidence in what they do, and will try as much as possible to carry out the tasks. As stated by Agustian "keeping promises is a golden step that can be done to achieve trust and achievement" [24].

Given the importance of the commitment for good work, it is important for the principal to increase the commitment of himself and the teachers. It can be done by: (1) providing support and also pressure. Teacher's commitment will be high if the principal is always willing to provide assistance to the problems faced or experienced by teachers in performing their duties. However, this support will be effective if accompanied by pressure. Support without pressure will be useless. Conversely, pressure without support will also be in vain, and it can even lead to conflicts and stress. Therefore, in addition to providing support by listening to teacher problems and providing adequate learning facilities and infrastructures; the principal must also dare to reprimand the teacher who did not perform the tasks well, or ask the teachers to do their duties properly. In other words, the principal must be able to enforce the rules that have been agreed upon. However, in reprimanding the teachers; (2) establishing quality standards to be achieved and academic rules that have been agreed upon, and implement these rules to achieve the quality standards; and (3) developing awarness and belief that quality of performance is important. Principals and teachers must have the awareness and belief that quality of performance is important, and have a strong determination and sense of attachment to maintain and improve the quality of work.

\subsubsection{Provide Supportive Leadership}

Good performance is the result of good empowerment of each individual, including the teacher. Therefore, the principal should be able to empower his/her teachers so that they become more able to carry out their duties. Leadership that makes people feel more empowered is supportive leadership. It is a leadership that can motivate and facilitate for the implementation of a good task.

As noted earlier, enforcement of rules or regulations will not work well without the convenience for teachers to access or obtain the facilities they need in performing the task. So in this case, if the principal wants to improve the performance of teachers, then the principal must be able and willing to seek various facilities that teachers need to be able to carry out their duties properly, and willing and able to be a good listener, involving teachers in decision making, and treating teachers as professionals.

\subsubsection{Make Working Condition Enjoyable}

Many studies have found that the conditions or places in which a person performs his/her work will have a significant effect on his performance. A pleasant, safe, comfortable, and clean workplace with all the office furniture neatly arranged, and all facilities needed are available will make people feel comfortable to work, and it will ultimately improve their performance. Conversely, messy workplace and with insufficient supporting facilities will make people feel uncomfortable and become lazy to work, even frustrated.

In order to improve the performance of teachers, it is necessary for the principal to do several things: (1) develop a comfortable school environment, teacher lounges, refrigerators for all rooms, telephone, and internet; (2) complete the office and laboratory equipment; (3) computerized administration; and (4) complete the library 
collection. All these facilities need to be maintained properly.

\subsubsection{Fix Process and Procedure}

The low quality of work is usually due to the lack of proper, for example the procedure of the School Meetings. Sometimes, the school meeting is only attended by some teachers. Although many are present, they are often late and then leave the meeting room before the meeting is over. Teachers' absence in this meeting is not always caused by laziness, but it is often caused by mistakes from schools where invitations are sometimes so sudden, and sometimes the teachers do not know about it.

Therefore, to improve the performance of teachers, it is necessary for the principal to review the work procedures used whether it has brought the expected results. If not, then the procedure needs to be fixed. Any new work procedure has to be tested fisrt before it is implemented. If the result were satisfied, then the procedure can be adopted.

\subsubsection{Give Recognition and Appreciation}

Awarding or acknowledging an employee who has done a good job will result in the employee becoming more enthusiastic the work. As Crushway noted that the rewards given to employees will increase employees' awareness of the organization's main goals and encourage them to work harder [25]. Therefore, in order to improve the performance of teachers, it is important for the principal to give recognition and appreciation to teachers who have tried to improve or have performed well. These recognition and appreciation should be given to teachers as soon as possible, otherwise they will be useless. In addition, schools also need to develop a system of recognition and rewards or a good incentive system. Failure of an organization in cooperation and in achieving goals is sometimes caused by the poor incentive system.

\subsubsection{Develop Teachers' Self-Efficacy}

The effectiveness of teaching and learning process not only needs teachers' competencies; but it also needs teachers' belief in their abilities to do the works properly. As Gist \& Mitchell said that teacher who has the same level of competencies but has different belief in his/her ability in implementing the taks, will shows different results or different level of performance [26]. The confidence of the teachers that they are able to carry out their task is called as self-efficacy of the teacher. According to Tschannen-Moran and Woolfolk Hoy, teacher self- efficacy is teacher's belief about his/her ability to help students in achieving their intended goals of education [27]. This belief of ability in helping students not only for normal students, but also for students with many difficulties. Theacher who has high self-efficacy will fell more confidance in carrying out his/her tasks and function; more capable in motivating student to learn, and also more capable in helping student to solve their problems [28]. Thus, teacher self-efficacy is a very important aspect for teacher good performance. Without teacher's belief of his/her ability to do the works properly; it will be difficult for the teacher to has good performance. Therefore, teacher self-efficacy needs to be develop by school principal. There are several things that can be done by school principal in developing teacher self-efficacy, such as:

a) Helping teachers to have successful experiences in conducting their tasks (mastery experience). According to Hoy \& Miskel, it is very important for teachers to have experiences in conducting the tasks succesfully[23]. By having successful experiences can make teachers belief in their ability; make teachers belief that they can do their job as they are expected to do. The feeling of capableness of the teachers in doing their tasks will increase their self-efficacy. Therefore, it is important for the principal to give teachers task that they can accomplish properly. In other words, in order to help teachers to have successful experiences, it is importance for the principal not to give teachers, especially new teachers, a very difficult task. If the teacher has difficulties in conducting their tasks, it is importance for the principal to help them, give them a guidance and confidence to accomplish their tasks. Beside that, it should be keep in mind by the principal that the teachers' abilities and skills for conducting their tasks need to be developed continuously.

b) Showing a model how to do the works to the teachers (modeling). Seeing or visualizing people similar to oneself successfully perform a task can raise one's own beliefs about self-efficacy. By observing people modeling certain behaviors, individuals convince themselves that if others can do it, so they can do it too, at least they can achieve some improvement in their own performance. In other words, by showing a model, a belief in oneself can be arised, and he/she can say "If other people can do, why I can't? I belief I can do it too!"

c) Persuade or convince teachers, by using words, that they can do their job well (verbal persuasion). According to Bandura, verbal persuasion can promote the development of skills and the feeling of self-efficacy [29]. Verbal 
persuasion widely used to try to talk to people into believing that they have the capacity to achieve what they want to accomplish. In persuading the teachers, the school principal can says to te teachers "I am sure that you are able to perform your task properly"; or the principal may says: "I'm sure that you can do it, so please try it". In this case, it is very importance for the principal to encourage teachers not to affraid to try or to do experiments, and not to affraid to make a mistake or to be failures. If the teachers made a mistake or experiencing a failure in the implementation of their work or their experiments, it is important for the principal to help teachers, and always encourage them, gives them spirit by saying: "Make a mistakes or experiencing the failures are common things; it is not a big deal and not a big crime". Make a mistake and experiencing failures are the nature of the human being. By making a mistake or failures, teachers will know where the error they have been made, and they know what causes they fail". Thus, error and failure can provide many lessons in the development of teachers' abilities and skills; and ofcource, the development of abilities and skills will bring about the inreasing in teachers' self-efficacy.

d) Increasing the healthtyness of physical and psychological conditions of the teachers. People generally rely on their physical and psychological condition to say that they are able or not to do their job. Individuals make judgments about their works based on the positive healthtyness arousal, such as excitement and enthusiasm; and on negative factors, such as fear, anxiety, and stress. Therefore, increasing the physical and psychological conditions of the teachers are very important to be done by school principal. Increasing teachers' physical healthtyness can be done by: (1) keeping the school environment safe from any other destructions; (2) providing office for the teachers. This office should be keep clean and net, has adequate lighting and good air circulation, and also should has clean and adequate restrooms; (3) providing sport facilities and encourage teachers to do some sport together; and (4) maintaining the school yard nice and clean. Increasing teachers' psychological conditions can be done by creating and maintaining a good school climate. It can be done by: (1) involving teachers in decision making; (2) conducting social activities, such as recreation, wirid, and visiting each other; (3) being fair to the teachers, consistent and fair in implementing rules and regulations, and (4) listening and helping teachers with their problems, include personal problems.

\section{CONCLUSIONS}

From the above description, it can be concluded that the performance of teachers is very important for the success of schools in achieving the educational goals. Through the optimal performance of teachers, it will improve the effectiveness and quality of education in schools, because teachers who have good performance will provide good results, both in quantity and quality.

Since performance of teachers sometimes is not as expected, it should always be improved. There are several ways that the school principal can improve teacher performance. They are including: (1) make the school as a healthy institution. This can be done by formulating the clear school's vision, mission, and objectives; having mutually agreed strategies to achieve the vision, mission and objectives; developing the necessary human resources; having a reliable administration; having a good academic program; developing intimate fellowship; and having a set of school cultures that equally upheld; (2) develop teacher professional skills. This can be done by encouraging teachers to take professional action, participating in professional meetings, being active in KKG activities, and scheduling time for professional discussions; (3) Increase teamwork. This can be done by creating a conducive organizational climate, developing an intimate atmosphere of equality, and resolving conflicts; (4) Have determination to become a quality school. This can be done by focusing attention on customers and establishing quality improvement teams; (5) increase teacher commitment. This can be done by providing balanced support and pressure to teachers, setting quality standards, and determining to improve quality; (6) provide supportive leadership. This can be done by empowering, motivating, and facilitating the implementation of the teacher's duties properly; (7) create enjoyable working conditions. This can be done by developing a safe, comfortable, and fun working environment; (8) fix processes and procedures. This can be done by developing standard operating procedures; (9) provide recognition and appreciation. This can be done by developing a good incentive system; and (10) increasing teacher self-efficacy. This can be done by giving teachers mastery working experiences, showing a model to teachers how to do the work, convincing teachers using verbal persuation, and inceeasing teachers' physical and emotional healthtyness. 


\section{ACKNOWLEDGEMENTS}

A short acknowledgement section can be written between the conclusion and the references. Sponsorship and financial support acknowledgments should be included here. Acknowledging the contributions of other colleagues who are not included in the authorship of this paper is also added in this section.

\section{REFERENCES}

[1] J.D. Willems, Monitoring School Performance: A Guide for Educators, London: Falmer Press, 1992.

[2] B.P.M. Creemers, "The history, value and purpose of school effectiveness studies", in Reynolds et al. (Eds), Advances in School Effectiveness Research and Practice, Oxford: Pergamon, 1994.

[3] J. Scheerens, Improving School Effectiveness: Fundamentals of Educational Planning, UNESCO: International Institute for Educational Planning, 2000, pp. 1-137. Retreved on 18th of May 2017 from http://www.unesco.org/iiep

[4] H. Ozgan and M. Toprak, M., "Classroom effects on the effectiveness of a school", Journal of Educational and Instructional Studies in the World, Vol. 2, No. 2, 2012, pp. 102-109.

[5] A.E. Taiwo and A.A. James, "Teacher variables and school effectiveness in Ekiti State, Nigeria", International Journal of Humanities and Social Science, Vol. 5, No. 7, 2015, pp. $95-101$

[6] A. Butsankom, C. Sirishuthi, and P. Lammana, "the development effectiveness management model for sub-district secondary school", in Educational Research and Reviews, Vol. 11, No. 19, 2016, pp. 1790-1804. Retrieved on the 15th of May 2017 from http://www.academicjournals.org/ERR

[7] Yonprimai, "Kontribusi kepemimpinan kepala sekolah dan kecerdasan emotional terhadap kinerja guru SMP Negeri di Kecamatan Lengayang Kabupaten Pesisir Selatan”, 2014, Unpublished Tesis

[8] Y. Santoso, "Pengaruh gaya kepemimpinan kepala sekolah dan motivasi kerja guru terhadap kinerja guru SMP Negeri Kecamatan Koto XI Tarusan Kabupaten Pesisis Selatan", 2014, Unpublished Tesis.

[9] Y.D. Arefa, "Kontribusi motivasi berprestasi dan iklim komunikasi terhadap kinerja guru
SMK Seni dan Budaya di Kecamatan Lubuk Begalung Padang", 2015, Unpublished Tesis.

[10] Dianita, Dola, "Kontribusi insentif dan disiplin kerja terhadap kinerja guru SD di Kecamatan Koto Parik Gadang di Ateh”, 2016, Unpublished Tesis,

[11] Asbandi, "Dampak kebijakan mutasi kerja guru terhadap kinerja guru SD di Kecamatan X Kabupaten Solok Selatan”, 2016, Unpublished Tesis.

[12] J.L. Gibson, Ivan Sevich, and J.H. Donelly, "Organization" (translation), Jakarta: Bumi Aksara, 1989.

[13]A.P. Mangkunegara, "Manajemen Sumber Daya Manusia Perusahaan", Bandung: Rosdakarya, 2004

[14]N. Fatah, "Konsep Manajemen Berbasis Sekolah (MBS) dan Dewan Sekolah", Bandung: C.V. Pustaka Bani Quraisy, 2004

[15]A. Lako, "Kepemimpinan dan Kinerja Organisasi" Yogyakarta: Amara Books, 2004.

[16] S. Reksohadiwiryo, "Organisasi Perusahaan", Yogyakarta: BPFE, 2002.

[17] S. Sonnentag, J. Volmer, and A. Spychala, "Job performance", Sage Handbook Of Organizational Behavior, Vol.1 Ed. By Julian Barling, 2010, pp. 427-447.

[18] J.W. Johnson, "The relative importance of task and contextual performance dimensions to supervisor judgments of overall performance", Journal of Applied Psychology, Vol. 86, 2001, pp. 984-996

[19]R.M. Steers, Organizational Effectiveness, Efektivitas Organisasi, Translated by Erlangga Team. Jakarta: Erlangga, 1992.

[20] Timpe, A.D. (1993). "Kinerja", translated by Sofyan Cikimat. Jakarta: Gramedia Asri Media

[21] P. Hersey, K.H. Blanchard, and D.E. Johnson, Management of Organizational Behavior: Leading Human Resources, NJ: Prentice Hall, 2008.

[22]P. Simanjuntak, Manajemen dan Evaluasi Kinerja. Jakarta: Lembaga Penerbit Fakultas Ekonomi Universitas Indonesia, 2005.

[23] W.K. Hoy and C.G. Miskel, Educational Administration: Theory, Research and Practice, New York: McGrow-Hill, 2013.

[24]A.G. Agustian, Rahasia Sukses Membargo Kecerdasan Emosi dan Spiritual (ESQ) Berdasarkan 6 Rukun Iman dan 5 Rukun Islam, Jakarta: Arga, 2004.

[25]B. Crushway, Human Resource Management, Jakarta: Alex Media Komputindo, 1999.

[26] M.E. Gist and T.R. Mitchell, "Self-efficacy: A theoretical analysis of its determinants and malleability", Academy of Management Review, Vol. 17, No. 2, 1992, pp. 183-211 
[27]M. Tscannen-Moran and A. Woolfolk-Hoy, "Teacher efficacy: Capturing an elusive construct", Teaching and Teacher Education Vol.17, 2001, pp. 783-805.

[28]A. Woolfolk Hoy, W.K. Hoy, and H. Davis, "Teachers' self-efficacy beliefs", in K. Wentzeland and A. Wigfield, Eds., Handbook of Motivation in School, Mahwah, NJ: Lawrence Erlbaum, 2009, pp.627-655.

[29] A. Bandura, "Exercise of human agency through collective efficacy", Current Directions in Psychological Science, Vol. 9 No. 1, 2000, pp. 75-78. 